\title{
Corrosion Study for the Effluent Treatment Facility Chrome (VI) Reductant Solution Using 304 and 316L Stainless Steel
}

\author{
J. B. Duncan and R. B. Wyras \\ CH2M HILL Hanford Group, Inc. \\ Richland, WA 99352 \\ U.S. Department of Energy Contract DE-AC27-99RL14047 \\ EDT/ECN: DRF UC: \\ Cost Center: 7S110 Charge Code: \\ B\&R Code: Total Pages: 30
}

Key Words: Effluent Treatment Facility, oxidation reduction potential, cyclic potentiodynamic polarization, test, solutions, linear polarization resistance, open circuit potential, secondary waste receiving tank, spent resin, 304 and 316L stainless steel, chrome (VI), chrome (III), sodium sulfate, sodium metabisulfite, WSFS, groundwater pump, plume, DOWEX, RPP-RPT-32207

Abstract: This report documents the laboratory testing and analyses as directed under the test plan, RPP PLAN-34065, and documented in laboratory notebooks HNF 2742 and HNF-N-473-1. The purpose of this study was to evaluate and compare the electrochemical corrosion and pitting susceptibility of the 304 and $316 \mathrm{~L}$ stainless steel in the acidified reducing solution that will be contained in either the secondary waste receiving tank or concentrate tank.

TRADEMARK DISCLAIMER. Reference herein to any specific commercial product, process, or service by trade name, trademark, manufacturer, or otherwise, does not necessarily constitute or imply its endorsement, recommendation, or favoring by the United States Government or any agency thereof or its contractors or subcontractors.

Printed in the United States of America. To obtain copies of this document, contact: Document Control Services, P.O. Box 950, Mailstop H6-08, Richland WA 99352, Phone (509) 372-2420; Fax (509) 376-4989.

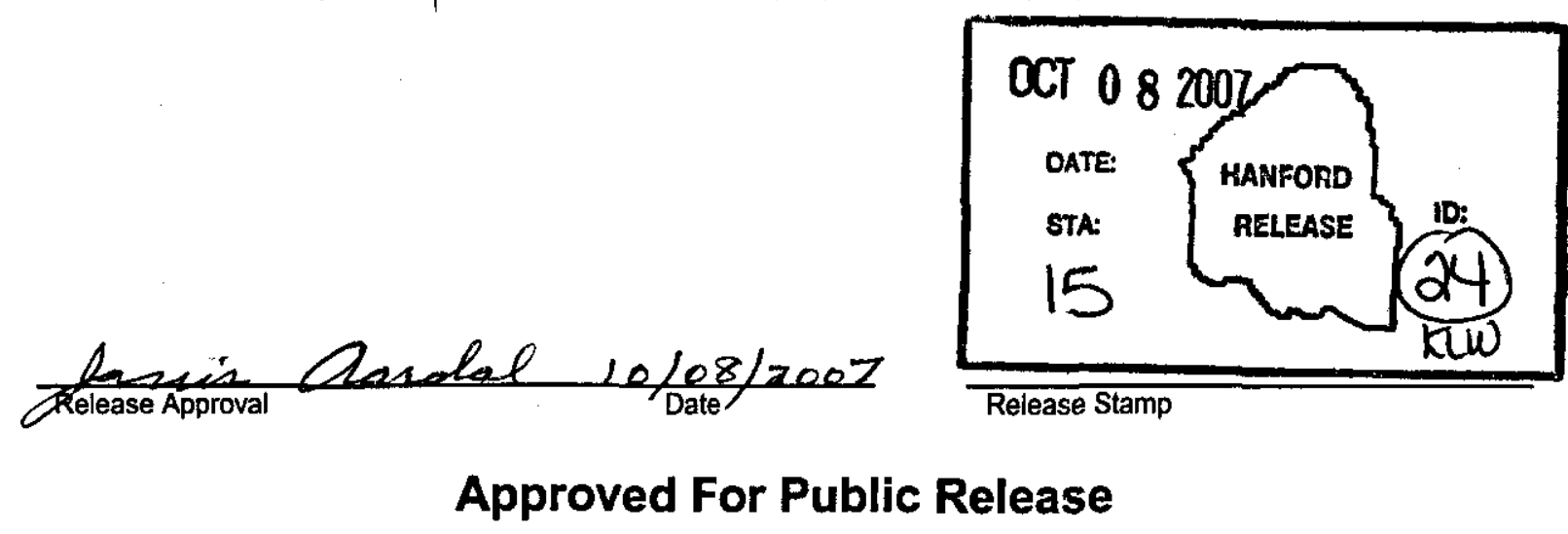


RPP-RPT-35175

Revision 0

Corrosion Study for the Effluent Treatment Facility Chrome (VI) Reductant Solution Using 304 and $316 \mathrm{~L}$ Stainless Steel

R. B. Wyrwas

RJ Lee Group, Inc.

J. B. Duncan

CH2M HILL Hanford Group, Inc.

October 2007

\section{CH2NHILL \\ Hanford Group, Inc.}

Prepared for the U.S. Department of Energy

Office of River Protection

Contract No. DE-AC27-99RL14047 


\section{Table of Contents}

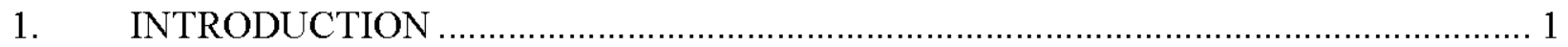

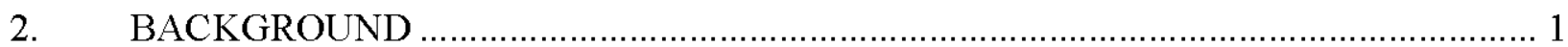

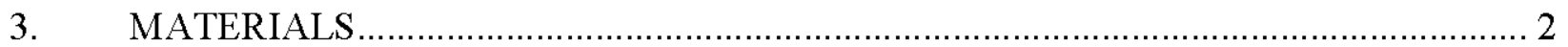

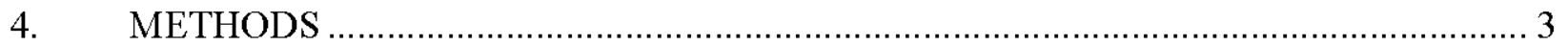

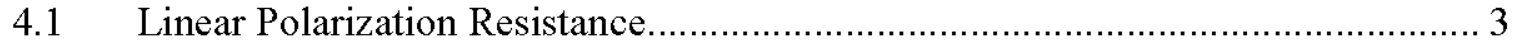

4.2 Cyclic Potentiodynamic Polarization................................................................. 4

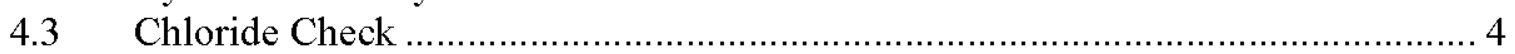

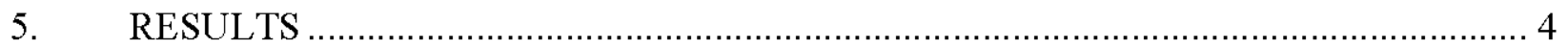

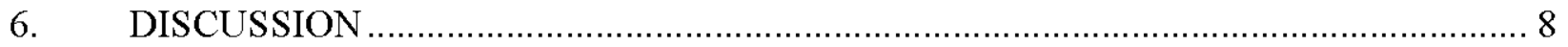

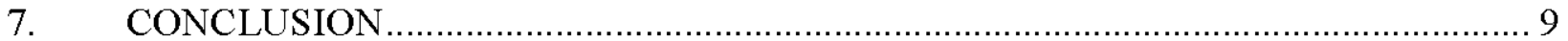

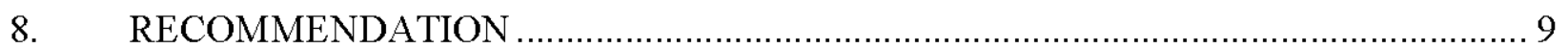

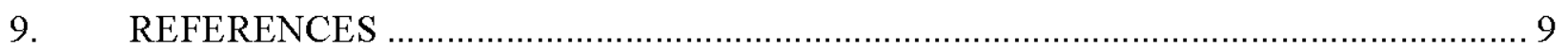

APPENDIX A Experimental Data ............................................................................. A

Figures

Figure 1. Oxidation-Reduction Potential mV versus Reagent Addition.................................. 2

Figure 2. Weight Loss versus Concentration of Sulfuric Acid........................................... 6

Figure 3. Photograph of 304 Stainless Steel Coupon after Exposure to Solution 1. ................. 6

Figure 4. Cyclic Potentiodynamic Polarization Scan of 304 Stainless Steel in

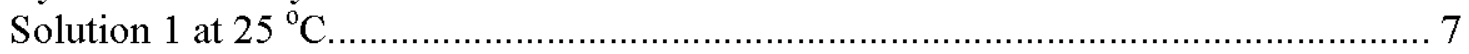

Figure 5. Cyclic Potentiodynamic Polarization Scan of $316 \mathrm{~L}$ Stainless Steel in 100-ppm Chloride Solution after Pre-treatment in Solution 1 for 1 Hour. ................... 7

Figure 6. 316L Stainless Steel Coupon Exposed to Solution 1......................................... 8

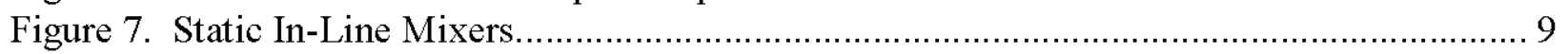

\section{Tables}

Table 1. Test Solutions.

Table 2. Results for Cyclic Potentiodynamic Polarization Studies Performed on 304 and 316L Stainless Steel in Test Solutions and 100-ppm Chloride Solution. (2 sheets) ............... 4

Table 3. Percent Composition of 304 and 316L Stainless Steel........................................... 5 
RPP-RPT-35175, Rev. 0

\section{List of Terms}
Abbreviations
CPP
cyclic potentiodynamic polarization
ETF
Effluent Treatment Facility
OCP
open circuit potential
ORP
oxidation reduction potential
SCE
saturated calomel electrode
SWRT
secondary waste receiving tank 


\section{INTRODUCTION}

This report documents the laboratory testing and analyses as directed under the test plan, RPP-PLAN-34065, Corrosion Study for the Effluent Treatment Facility Chrome (VI) Reductant Solution Using 304 and $316 \mathrm{~L}$ Stainless Steel, and documented in laboratory notebooks HNF-274-2 and HNF-N-473-1. The purpose of this study was to evaluate and compare the electrochemical corrosion and pitting susceptibility of the 304 and 316L stainless steel in the acidified reducing solution that will be contained in either the secondary waste receiving tank (SWRT) or concentrate tank.

\section{BACKGROUND}

The Effluent Treatment Facility (ETF) developed a method to regenerate spent resin from the groundwater pump and treat intercepting chrome (VI) plumes (RPP-RPT-32207, Laboratory Study on Regeneration of Spent DOWEX $X^{1} 21 \mathrm{~K}$ 16-20 Mesh Ion Exchange Resin). Subsequent laboratory studies have shown that the chrome (VI) may be reduced to chrome (III) by titrating with sodium metabisulfite to an oxidation reduction potential (ORP) of $+280 \mathrm{mV}$ at a $\mathrm{pH}$ of 2 . Equations 1 and 2 give the stoichiometric relationships involved in the reactions (Pollution Prevention and Control Technology for Plating Operations, Cushnie 1994).

$$
\mathrm{Na}_{2} \mathrm{~S}_{2} \mathrm{O}_{5}+\mathrm{H}_{2} \mathrm{O} \rightarrow 2 \mathrm{NaHSO}_{3}
$$

Then

$$
3 \mathrm{NaHSO}_{3}+2 \mathrm{H}_{2} \mathrm{CrO}_{4}+3 \mathrm{H}_{2} \mathrm{SO}_{4} \rightarrow \mathrm{Cr}_{2}\left(\mathrm{SO}_{4}\right)_{3}+5 \mathrm{H}_{2} \mathrm{O}+3 \mathrm{NaHSO}_{4}
$$

Figure 1 shows the ORP versus the sodium metabisulfite reagent addition to achieve the reduced chrome (III) species (Application Data Sheet ADS 3300-02/rev.A, pH and ORP Control for Removing Chrome from Plant Effluent).

To regenerate the spent ion exchange resin, several bed volumes of $0.5 \mathrm{M}$ sodium sulfate were used to displace the chrome (VI) from the resin. This resulted in a large volume of sodium sulfate and chrome (VI). The chrome (VI) was then reduced to chrome (III) at a pH of 2 with sodium metabisulfite. The reduction took place in either the SWRT or the concentrate tank. The material of construction for the SWRT is 304 stainless steel and the concentrate tank is 316L stainless steel.

\footnotetext{
${ }^{1} \mathrm{DOWEX}^{\mathrm{TM}}$ is a registered trademark of Dow Chemical Company, Midland, Michigan.
} 


\section{Figure 1. Oxidation-Reduction Potential mV versus Reagent Addition.}

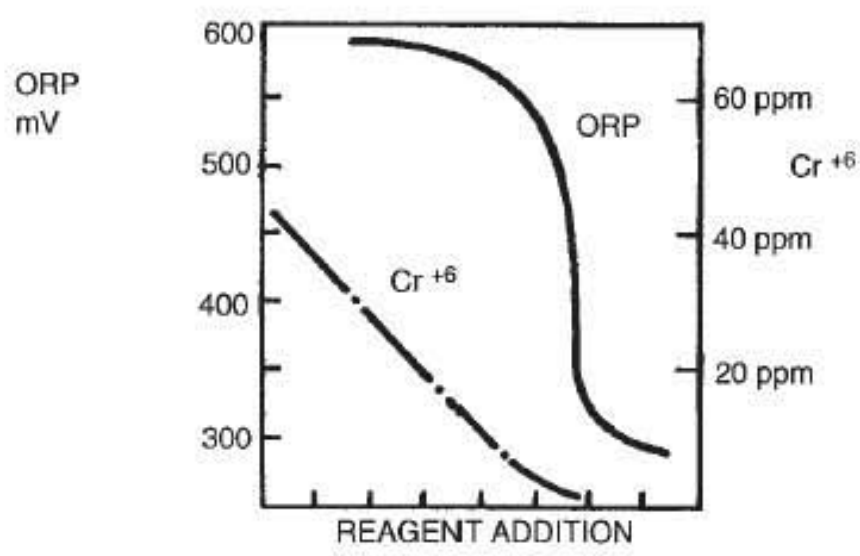

The test plan described the use of cyclic potentiodynamic polarization and linear polarization techniques to ascertain the electrochemical corrosion and pitting propensity of the 304 and $316 \mathrm{~L}$ stainless steel in the acidified reducing solution that was contained in either the SWRT or concentrate tank

\section{MATERIALS}

Sample coupons fabricated using 304 and $316 \mathrm{~L}$ stainless steel with a surface area of 5.64 in. $^{3}$ were procured from Metal Samples ${ }^{3}$. The coupons were factory polished and stored in inhibiting paper. Before conditioning the coupons in the test solutions, the coupons were polished with 600 -grit sandpaper to remove any possible oxide coating and contaminants. The coupons were then subsequently sonicated for 3 minutes in acetone and rinsed with hexane.

The solutions in Table 1 were generated using reagent grade materials with the respective concentrations. Sodium dichromate was used as the source of chrome (VI). Sulfuric acid was added to each solution until a $\mathrm{pH}$ of 2 was reached. $\mathrm{A}$ fourth test solution was later added to this solution set that contained $100 \mathrm{ppm}$ of chloride at $\mathrm{pH}$ of 7 . The solution was made with $0.165 \mathrm{~g}$ of sodium chloride in $1 \mathrm{~L}$ of deionized water.

Table 1. Test Solutions.

\begin{tabular}{|c|c|c|c|c|}
\hline $\begin{array}{c}\text { Test Solution } \\
\left(\mathbf{T}=\mathbf{l 4 0}^{\circ} \mathbf{F}\right)\end{array}$ & Sodium Sulfate & Chrome (VI) & Sulfuric Acid & $\begin{array}{c}\text { Sodium } \\
\text { Metabisulfite }\end{array}$ \\
\hline Test Solution 1 & $4 \%$ & $50 \mathrm{pm}$ & $\mathrm{pH}$ & $300 \mathrm{pm}$ \\
\hline Test Solution 2 & $4 \%$ & $50 \mathrm{ppm}$ & $\mathrm{pH} 2$ & NA \\
\hline Test Solution 3 & $\mathrm{NA}$ & $\mathrm{NA}$ & $\mathrm{pH} 2$ & NA \\
\hline
\end{tabular}

All weighing'handling of chrome (VI) was carried out in a chemical hood. Also, all chrome (VI) solutions were converted to chrome (III) with sodium m etabisulfite.

\footnotetext{
${ }^{2}$ Metal Samples ${ }^{\text {is }}$ is a division of Alabama Specialty Products, Munford, Alabama
} 


\section{METHODS}

The electrochemical testing in this report was conducted using a VMP2 multipotentiostat manufactured by Princeton Applied Research ${ }^{\circledR}$. The electrochemical cell design was an adapted version as described in ASTM G5-94, Standard Reference Test Method for Making Potentiostatic and Potentiodynamic Anodic Polarization Measurements. The 304 and 316L stainless-steel coupons were used as the work electrodes with graphite counter electrodes and a saturated calomel electrode (SCE) as the reference electrode. The instrument and electrochemical cell response were tested using the procedure described in ASTM G5-94, Standard Reference Test Method for Making Potentiostatic and Potentiodynamic Anodic Polarization Measurements.

The electrochemical corrosion testing included three parts: equilibration of the test coupon with the test solution, and then use of both linear polarization resistance (LPR) and cyclic potentiodynamic polarization (CPP) techniques. The CPP scans were conducted in accordance with ASTM G61-86, Standard Test Method for Conducting Cyclic Potentiodynamic Polarization Measurements for Localized Corrosion Susceptibility of Iron-, Nickel-, or Cobalt-Based Alloys. To emulate more realistic conditions, a set of CPP scans were run at $60^{\circ} \mathrm{C}$ for test solutions 1 through 3 and $38^{\circ} \mathrm{C}$ for the $100-\mathrm{ppm}$ chloride solution. During elevated temperature scans, the $\mathrm{SCE}$ was thermally isolated using a solution bridge and separate solution vessel.

The LPR and CPP are discussed in Sections 4.1 and 4.2. A more detailed description of these techniques are contained in RPP-PLAN-34065 and in An Introduction to Electrochemical Corrosion Testing for Practicing Engineers and Scientists (Tait 1994).

\subsection{LINEAR POLARIZATION RESISTANCE}

Linear polarization resistance is a nondestructive technique that uses a very small spectrum of overpotential from the open circuit potential (OCP) of the material in question. The coupon is scanned $\pm 20 \mathrm{mV}$ either side of the OCP. From the recorded spectrum, the corrosion resistance and corrosion currents can be extracted. Utilizing the corrosion current, $i_{\text {corr }}$ in units of $\mathrm{mA} / \mathrm{cm}^{2}$, the corrosion rate in mils/year (mpy) is calculated by the following:

$$
m p y=i_{c o r r}(\Lambda)(1 / \rho)(\varepsilon)
$$

where

$\Lambda=$ a combination of several terms and is

$1.2866 \mathrm{E} 05$ [equivalents $\cdot \mathrm{sec} \cdot \mathrm{mils}] /[$ coulombs $\cdot \mathrm{cm} \cdot$ years]

$\rho=$ metal density in $\mathrm{g} / \mathrm{cm}^{3}$

$\varepsilon=$ equivalent weight in g/equivalent.

For iron, the density is $7.87 \mathrm{~g} / \mathrm{cm}^{3}$ and the equivalent weight is $27.56 \mathrm{~g} /$ equivalent.

\footnotetext{
${ }^{3}$ Princeton Applied Research ${ }^{\circledR}$ is a business unit of Advanced Measurement Technologies, Inc., a division of AMETEK, Inc., Oak Ridge, Tennessee.
} 


\subsection{CYCLIC POTENTIODYNAMIC POLARIZATION}

Cyclic potentiodynamic polarization curves are an extension of the potentiodynamic polarization scan. The CPP reverses at a given potential or current density as described in ASTM G61-86.

The CPP curve is a destructive test, as opposed to the LPR, in that it will scan from $-250 \mathrm{mV}$ versus OCP through a designated potential (or current density) of approximately $+1000 \mathrm{mV}$ versus OCP before reversing. The information gathered from the scan includes the electrochemical corrosion [mils per year (mpy)], the primary passivation potential, the breakdown potential, and the repassivation potential. A positive or negative hysteresis is usually observed during a CPP scan. In the case of positive, the curve reverses with a higher current density indicating pit growth; whereas, with a negative hysteresis, the curve reverses with a lower current density indicating no pit growth.

\subsection{CHLORIDE CHECK}

Sample coupons of both 304 and 316L stainless steel were exposed to the metabisulfite mixture contained in solution one for a minimum time of 1 hour. After the elapsed time, a CPP scan was collected for each coupon in the 100 -ppm chloride solution at $38^{\circ} \mathrm{C}$.

\section{RESULTS}

The corrosion rate (mpy), corrosion current $\left(\mathrm{i}_{\text {corr }}\right)$, corrosion potential $\left(\mathrm{E}_{\text {corr }}\right)$, and chi squared ${ }^{4}$ $\left(\chi^{2}\right)$ are reported in Table 2 .

Table 2. Results for Cyclic Potentiodynamic Polarization Studies Performed on 304 and 316L Stainless Steel in Test Solutions and 100-ppm Chloride Solution. (2 sheets)

\begin{tabular}{|l|c|c|c|r|c|}
\hline Solution and Coupon & $\begin{array}{c}\text { Temperature } \\
\left({ }^{\circ} \mathbf{C}\right)\end{array}$ & $\begin{array}{c}\text { Corrosion Rate } \\
(\mathbf{m p y})\end{array}$ & $\mathbf{E}_{\text {corr }}(\mathbf{m V}$ vs. Ref) & $\mathbf{I}_{\text {corr }}(\boldsymbol{\mu} \mathbf{A})$ & $\boldsymbol{\chi}^{\mathbf{2}}$ \\
\hline Solution 1, 304 SS & 25 & 21.5454 & -442.22 & 265.176 & 11.7532 \\
\hline Solution 2, 304 SS & 25 & 0.0121 & 217.55 & 0.149 & 9.6666 \\
\hline Solution 3, 304 SS & 25 & 7.2460 & -407.95 & 89.182 & 15.4099 \\
\hline Solution 1, 316L SS & 25 & 27.9886 & -500.47 & 344.478 & 1.5342 \\
\hline Solution 2, 316L SS & 25 & $2.7625 \mathrm{E}-03$ & 162.97 & 0.034 & 54.6937 \\
\hline Solution 3, 316L SS & 25 & $2.0637 \mathrm{E}-02$ & 77.14 & 0.254 & 7.8542 \\
\hline Solution 1, 304 SS & 60 & 30.5096 & -513.642 & 187.753 & 45.8010 \\
\hline Solution 2, 304 SS & 60 & $1.3894 \mathrm{E}-02$ & 202.642 & 0.171 & 4.0551 \\
\hline Solution 3, 304 SS & 60 & 69.2031 & -462.545 & 851.737 & 2.3112 \\
\hline Solution 1, 316L SS & 60 & 29.1911 & -439.024 & 179.639 & 6.1085 \\
\hline Solution 2, 316L SS & 60 & $6.6625 \mathrm{E}-03$ & 133.66 & 0.082 & 7.2983 \\
\hline
\end{tabular}

\footnotetext{
${ }^{4}$ The value for chi squared $\left(\chi^{2}\right)$ is a measure of the error in the Tafel fitting algorithm or can alternatively be referred to as the goodness of fit. A value less than 100 is acceptable.
} 
Table 2. Results for Cyclic Potentiodynamic Polarization Studies Performed on 304 and 316L Stainless Steel in Test Solutions and 100-ppm Chloride Solution. ( 2 sheets)

\begin{tabular}{|l|c|c|c|c|c|}
\hline Solution and Coupon & $\begin{array}{c}\text { Temperature } \\
\left({ }^{\circ} \mathbf{C}\right)\end{array}$ & $\begin{array}{c}\text { Corrosion Rate } \\
(\mathbf{m p y})\end{array}$ & $\mathbf{E}_{\text {corr }}(\mathbf{m V}$ vs. Ref) & $\mathbf{I}_{\text {corr }}(\boldsymbol{\mu A})$ & $\boldsymbol{\chi}^{\mathbf{2}}$ \\
\hline Solution 3, 316L SS & 60 & $2.5025 \mathrm{E}-02$ & 257.543 & 0.308 & 5.3959 \\
\hline Chloride, 304 SS & 38 & 0.5451 & -67 & 6.709 & 217.224 \\
\hline Chloride, 316L SS & 38 & 0.0262 & 257.646 & 0.323 & 3.7754 \\
\hline
\end{tabular}

The corrosion rate for the $304 \mathrm{SS}$ in solution 3 (sulfuric acid, $\mathrm{pH} 2$ ) was greater than that of $316 \mathrm{~L} \mathrm{SS}$ by approximately 3400 times. The reason for this difference is in the composition of the two steel formulations (Table 3 ).

Table 3. Percent Composition of 304 and 316L Stainless Steel.

\begin{tabular}{|l|c|c|c|c|c|c|c|c|c|}
\hline Type & $\mathbf{C}$ & $\mathbf{M n}$ & $\mathbf{P}$ & $\mathbf{S}$ & $\mathbf{S i}$ & $\mathbf{C r}$ & $\mathbf{N i}$ & $\mathbf{N}$ & $\mathbf{M o}$ \\
\hline 304 & 0.08 & 2.0 & 0.045 & 0.030 & 1.00 & $18.0-20.0$ & $8.0-10.5$ & -- & -- \\
\hline 316L & 0.03 & 2.0 & 0.045 & 0.030 & 1.00 & $16.0-18.0$ & $10.0-14.0$ & -- & $2.0-3.0$ \\
\hline
\end{tabular}

Note: ASTM A 479A/479M-06a, Standard Specification for Stainless Steel Bars and Shapes for Use in Boilers and Other Pressure Vessels.

The addition of nickel with molybdenum to austenitic steel lends passivity to the steel against general corrosion in sulfuric acid. Figure 2 shows various steel formulation weight loss versus concentration of sulfuric acid (ASM Handbook). As can be determined by Figure 2, 304 stainless steel is more susceptible to attack by sulfuric acid than is $316 \mathrm{~L}$ stainless steel.

The photograph in Figure 3 shows the discoloration of the 304 stainless steel coupon after exposure to solution 1 , which contained sodium metabisulfite. The coupons were observed to turn black prior to CCP scans during the equilibration period of the experiment.

Cyclic potentiodynamic polarization scans for the $304 \mathrm{SS}$ in solution 1 and the $316 \mathrm{~L}$ SS in 100 -ppm chloride solution are shown in Figures 4 and 5, respectively. 
Figure 2. Weight Loss versus Concentration of Sulfuric Acid.

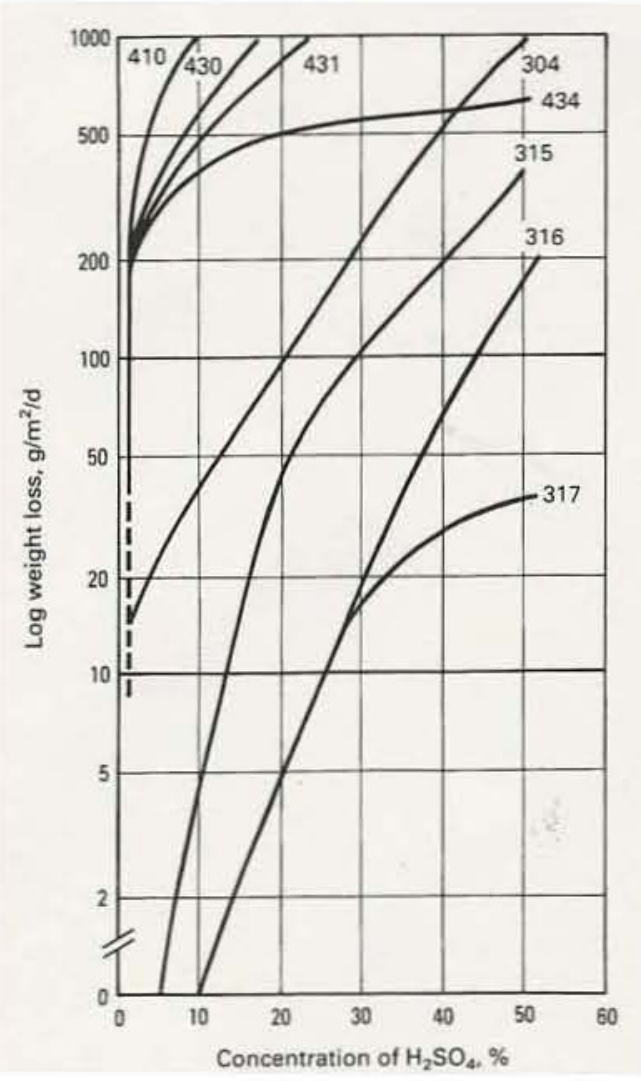

Figure 3. Photograph of 304 Stainless Steel Coupon after Exposure to Solution 1.

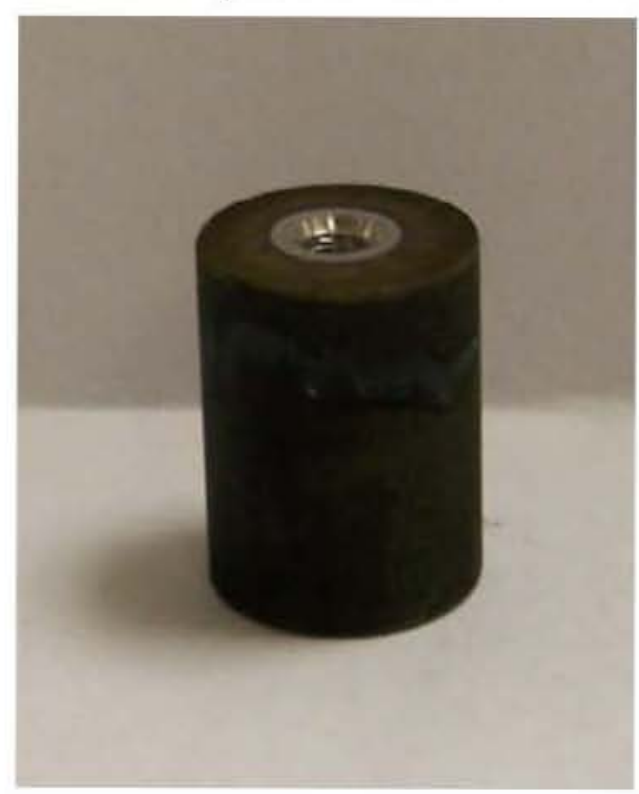


Figure 4. Cyclic Potentiodynamic Polarization Scan of 304 Stainless Steel in Solution 1 at $25^{\circ} \mathrm{C}$.

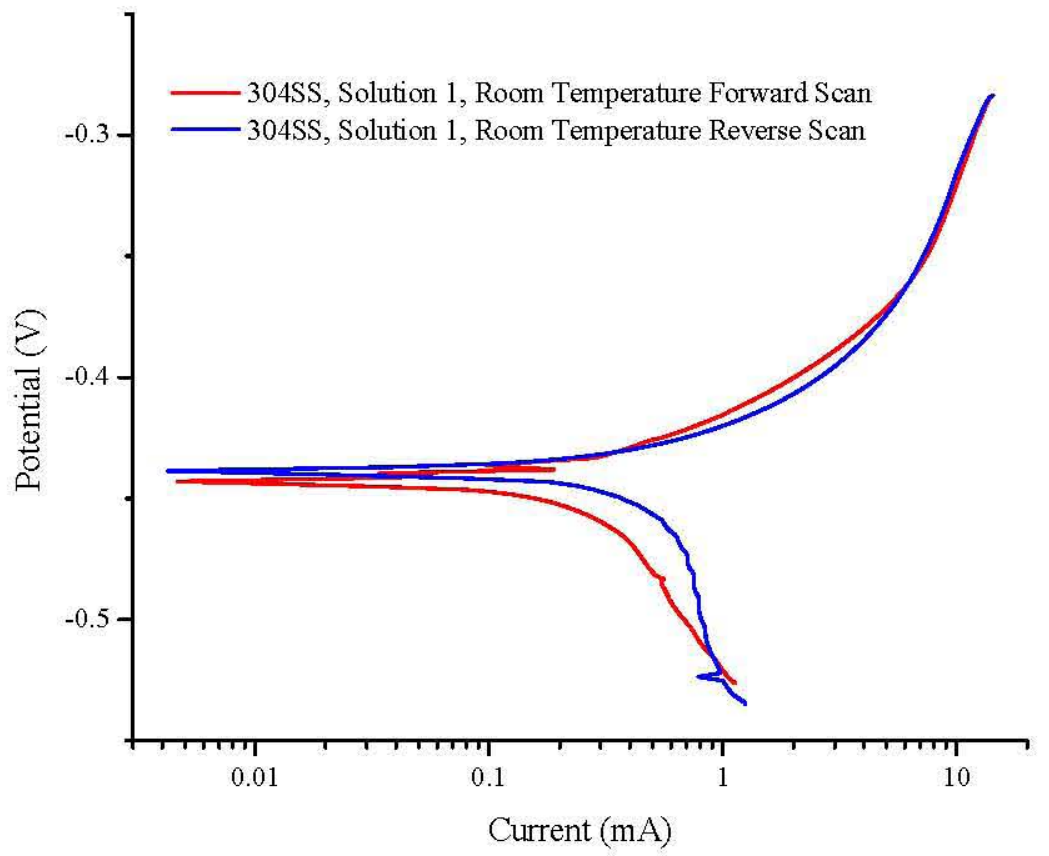

Figure 5. Cyclic Potentiodynamic Polarization Scan of 316L Stainless Steel in 100-ppm Chloride Solution after Pre-treatment in Solution 1 for 1 Hour.

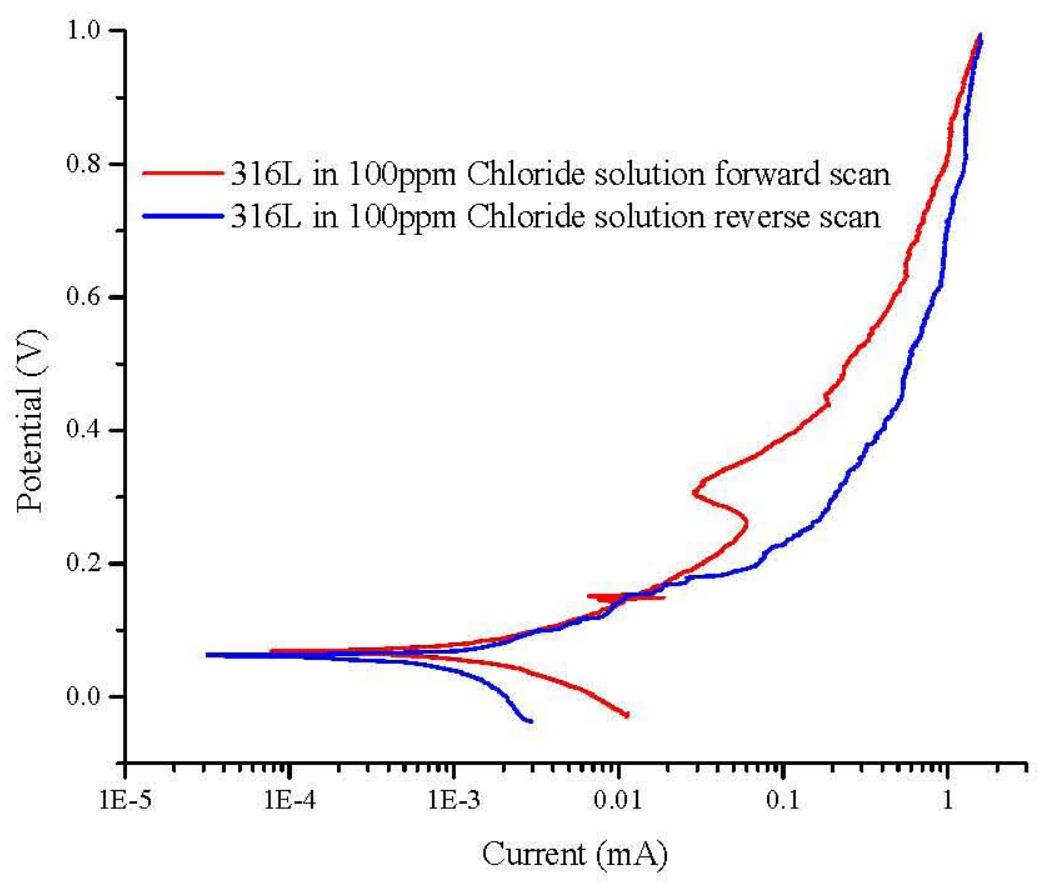


The coupon displayed in Figure 6 is an example of a 316L coupon after being exposed to solution 1 and then undergoing a CPP scan in a 100-ppm chloride solution.

\section{Figure 6. 316L Stainless Steel Coupon Exposed to Solution 1.}

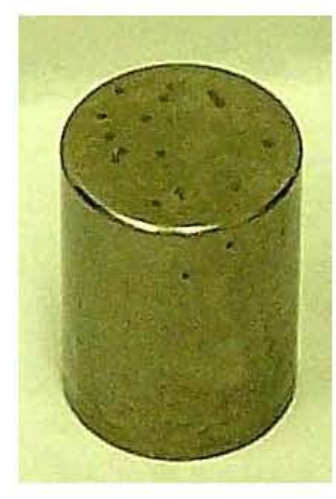

\section{DISCUSSION}

From the results shown in Table 1, solution 1, which contains the sodium metabisulfite, displays the most aggressive attack of the 304 and 316 stainless steel coupons. Increased temperature elevates the corrosion rates. The CPP scans allowed the laboratory to determine the pitting propensity of the 304 and $316 \mathrm{~L}$ stainless steel in the test solutions. For solution 1 at room temperature, a slight positive hysteresis was observed for both metals and more pronounced in the case of the $316 \mathrm{~L}$. At a higher temperature, the hysteresis is not evident. However, an oxide layer, as observed in Figure 2, was present after the scan had completed, indicating chemical attack of the coupon surface by the components of solution 1 . Since this attack was not observed with solutions 2 and 3 , it was determined that this coating is the result of the sodium metabisulfite reaction.

For solutions 2 and 3 at both $25^{\circ} \mathrm{C}$ and $60^{\circ} \mathrm{C}$, there was no evidence of pitting from the electrochemical scans collected. All scans at room temperature $\left(25^{\circ} \mathrm{C}\right)$ and at high temperature $\left(60^{\circ} \mathrm{C}\right)$ resulted in a negative hysteresis. The scans are displayed in Appendix A.

Although the sample coupons did not pit during exposure to the test solutions, the protective surface layer is extremely weakened; presumably due to the loss of those components $(\mathrm{Cr}, \mathrm{Ni}$, Mo) that allow the steel to maintain a passivated state to corrosive environments. This observation can be made in the scans where the coupons were preconditioned in (solution 1) and then exposed to the low-level chloride solution (100-ppm chloride in water) where pitting occurred. The positive hysteresis found in the CPP scan in Figure 4 is evidence of pitting. Furthermore, pits were observed on the coupons that were tested in the chloride solution as easily recognized by the dark surface spots in Figure 5. 


\section{CONCLUSION}

When exposed to sodium metabisulfite solution at a $\mathrm{pH}$ of $2.0,304$ and $316 \mathrm{~L}$ stainless steel were found to have high corrosion rates based on the electrochemical measurements performed for this study. Upon exposure to the acidified sodium metabisulfite solution, at open circuit potential, a black oxide immediately formed on the surface indicating a chemical reaction, Sample coupons that were exposed to the solution containing sodium metabisulfite then subsequently undergoing a CPP scan, demonstrated both electrochemical and visible pitting.

\section{RECOMMENDATION}

To process chrome (VI) to chrome (III) in a manner that is not deleterious to current tankage, inline static mixers are recommended to mix the sodium metabisulfite at $\mathrm{pH} 2$ as well as raise the $\mathrm{pH}$ before sending to the receiving tank (Figure 7). The material of construction would be chemistry compatible.

Figure 7. Static In-Line Mixers.

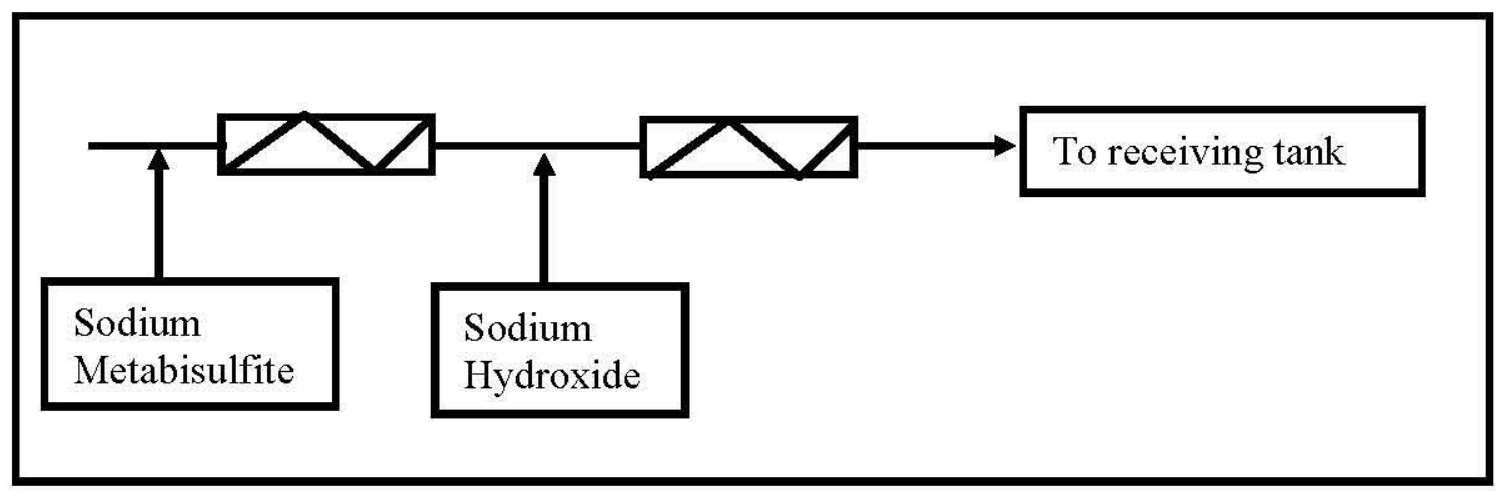

\section{REFERENCES}

Application Data Sheet, ADS 3300-02/rev.A, August 2004, pH and ORP Control for Removing Chrome from Plant Effluent, in Metals and Mineral Industry, Emerson Process Management, http://www.emersonprocess.com/raihome/documents/Liq AppData 330002.pdf.

ASM International Handbook, Corrosion Volume 13, Davis, JR Senior Editor, November 2001.

ASTM A 479/A 479M-06a (Approved 2006), Standard Specification for Stainless Steel Bars and Shapes for Use in Boilers and Other Pressure Vessels, ASTM International, West Conshohocken, Pennsylvania.

ASTM G5-94, 1994 (Reapproved 1999), Standard Reference Test Method for Making Potentiostatic and Potentiodynamic Anodic Polarization Measurements, ASTM International, West Conshohocken, Pennsylvania. 
ASTM G61-86, 1986 (Reapproved 2003), Standard Test Method for Conducting Cyclic Potentiodynamic Polarization Measurements for Localized Corrosion Susceptibility of Iron-, Nickel-, or Cobalt-Based Alloys, ASTM International, West Conshohocken, Pennsylvania.

Cushnie, G. C., 1994, Pollution Prevention and Control Technology for Plating Operations, National Center for Manufacturing Sciences, Ann Arbor, Michigan.

RPP-PLAN-34065, 2007, Corrosion Study for the Effluent Treatment Facility Chrome (VI) Reductant Solution Using 304 and 316 L Stainless Steel, Rev. 0, CH2M HILL Hanford Group, Richland, Washington.

RPP-RPT-32207, 2007, Laboratory Study on Regeneration of Spent DOWEX 21K 16-20 Mesh Ion Exchange Resin, Rev. 0, CH2M HILL Hanford Group, Richland, Washington.

Tait, W. S., 1994, "An Introduction to Electrochemical Corrosion Testing for Practicing Engineers and Scientists," PairODocs Publications, Racine, Wisconsin. 
RPP-RPT-35175, Rev. 0

APPENDIX A

Experimental Data 
Figure A-1. Cyclic Potentiodynamic Polarization Scan of 304 Stainless Steel in Solution 1 at $25^{\circ} \mathrm{C}$, Potential Versus Saturated Calomel Electrode.

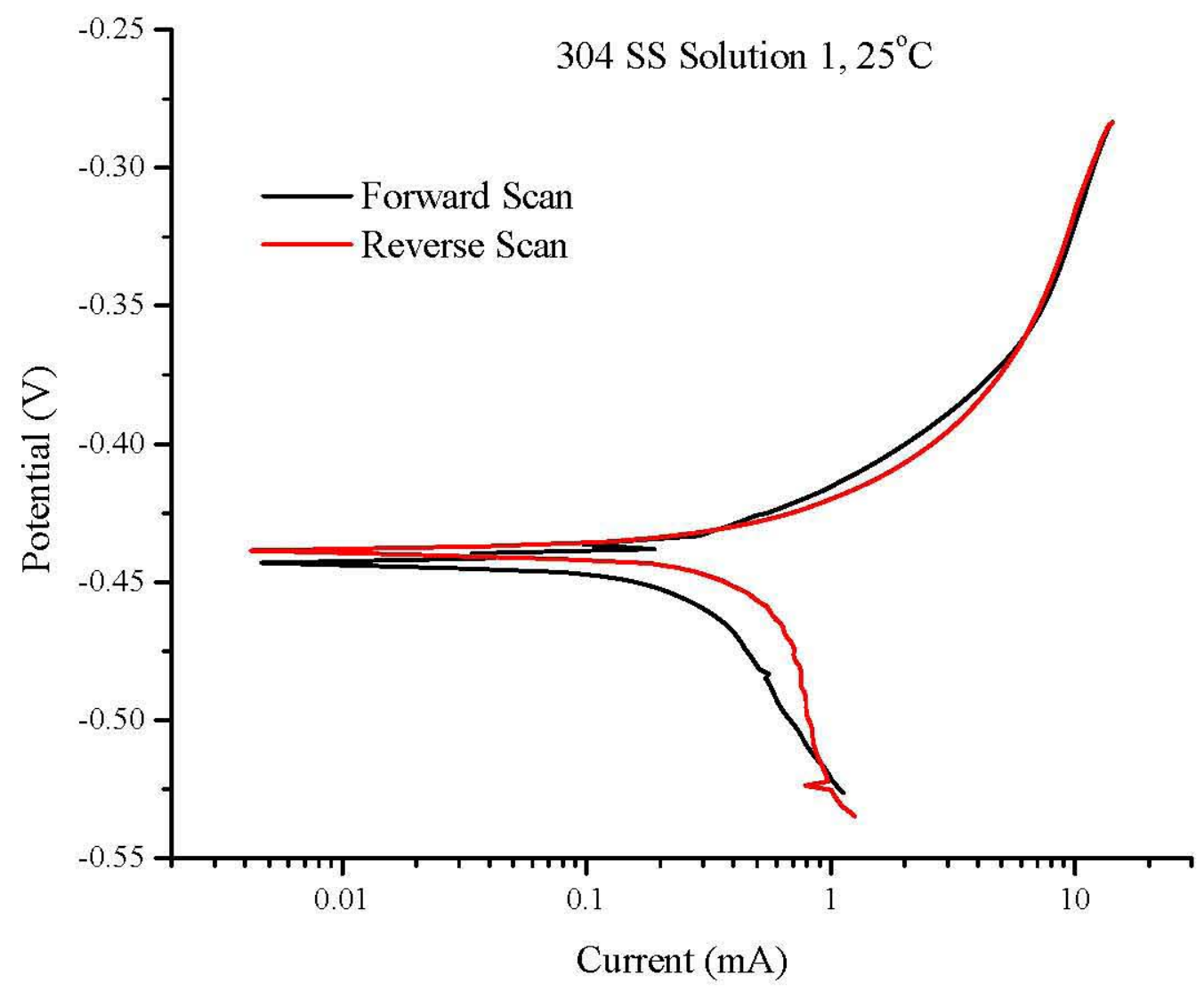


Figure A-2. Cyclic Potentiodynamic Polarization Scan of 304 Stainless Steel in Solution 2 at $25^{\circ} \mathrm{C}$, Potential Versus Saturated Calomel Electrode.

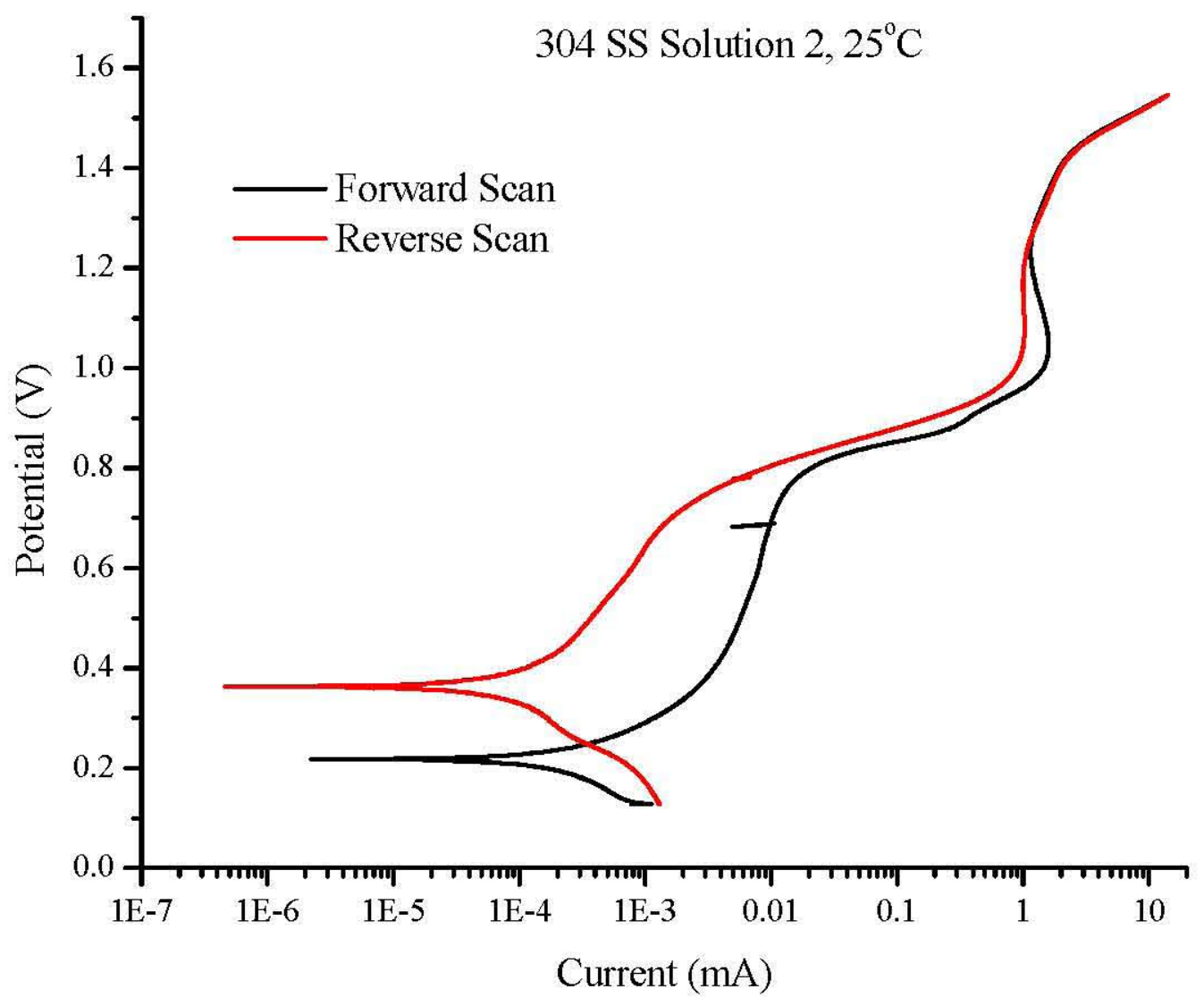


Figure A-3. Cyclic Potentiodynamic Polarization Scan of 304 Stainless Steel in Solution 3 at $25^{\circ} \mathrm{C}$, Potential Versus Saturated Calomel Electrode.

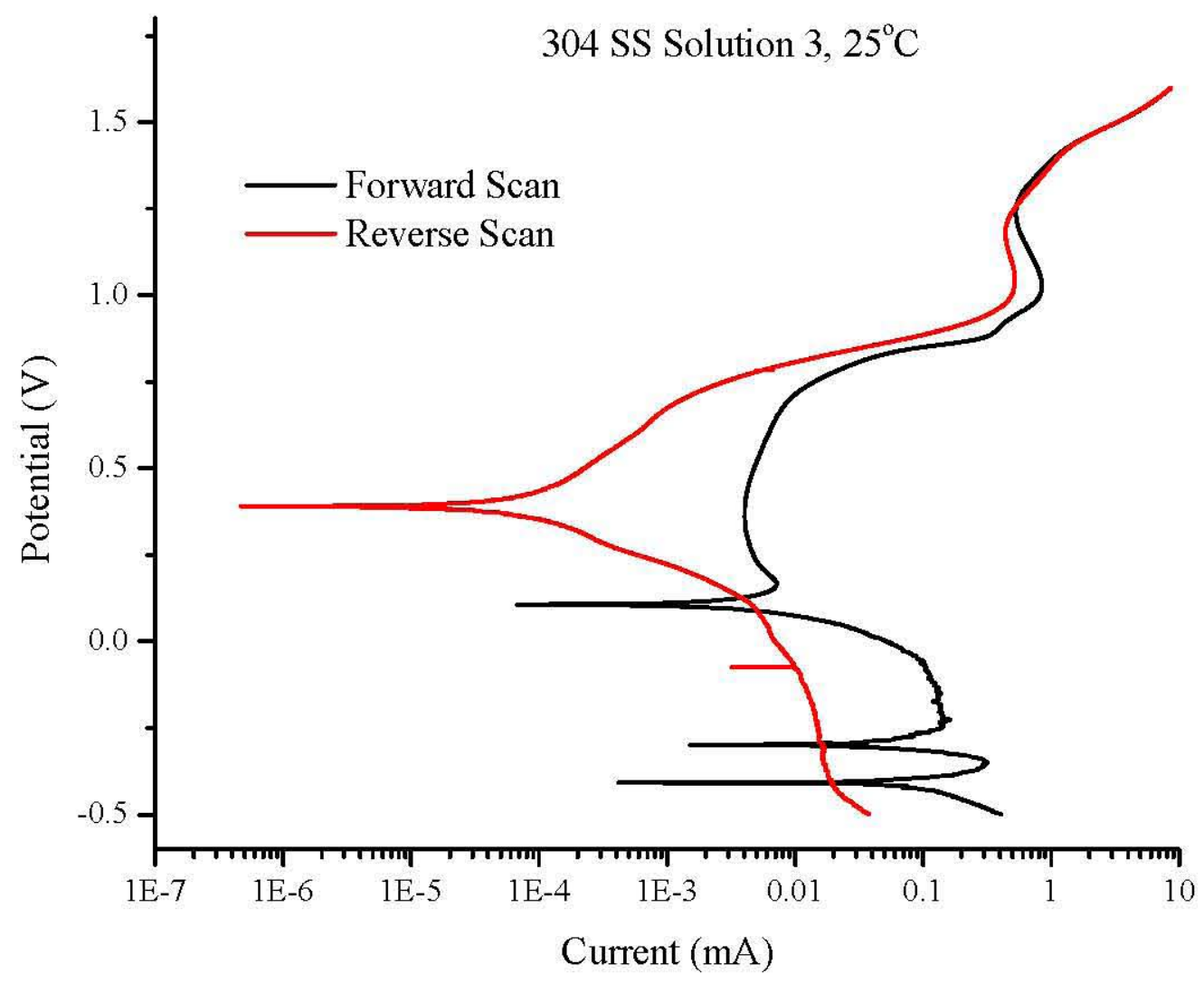


Figure A-4. Cyclic Potentiodynamic Polarization Scan of 316L Stainless Steel in Solution 1 at $25^{\circ} \mathrm{C}$, Potential Versus Saturated Calomel Electrode.

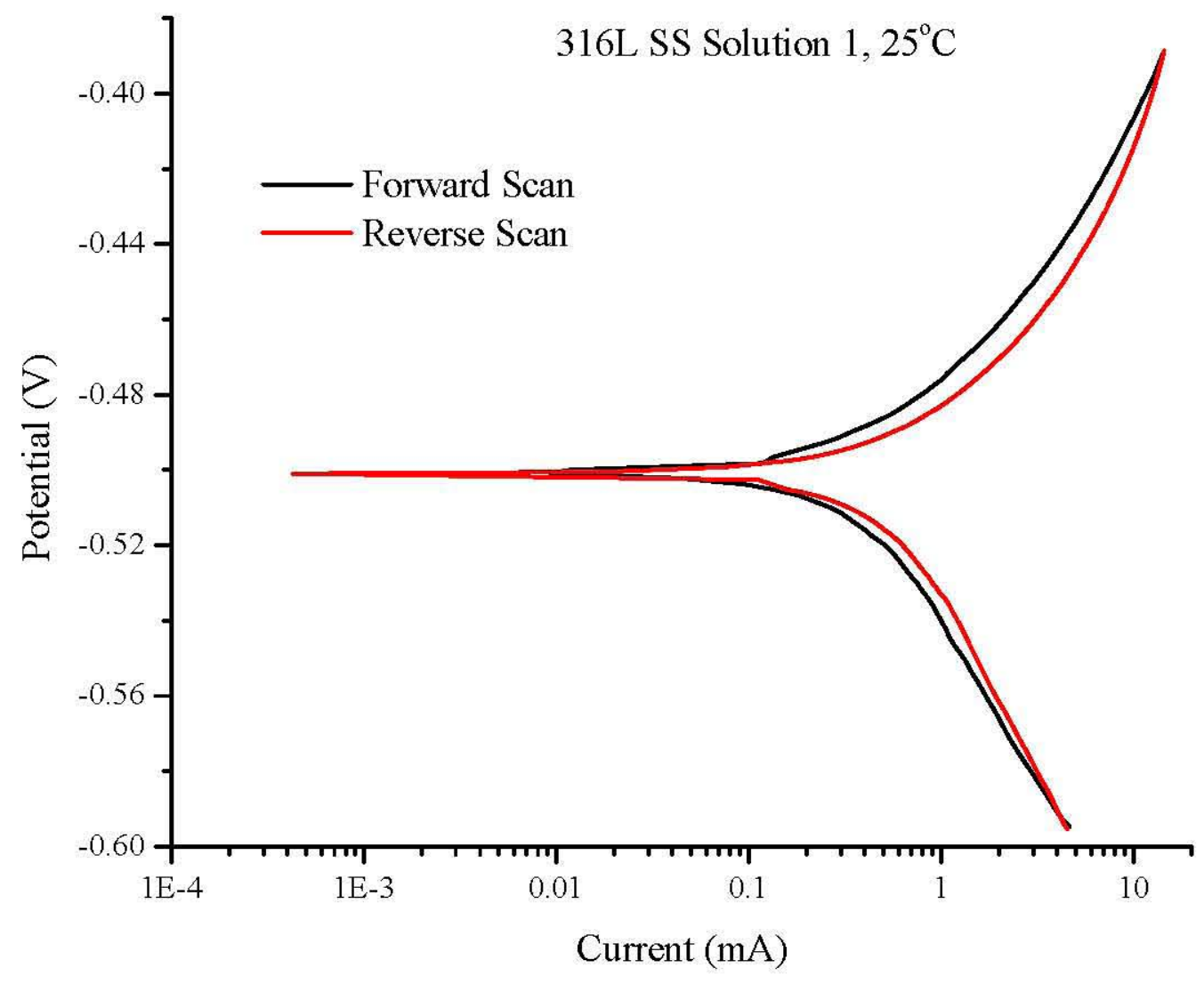


Figure A-5. Cyclic Potentiodynamic Polarization Scan of 316L Stainless Steel in Solution 2 at $25^{\circ} \mathrm{C}$, Potential Versus Saturated Calomel Electrode.

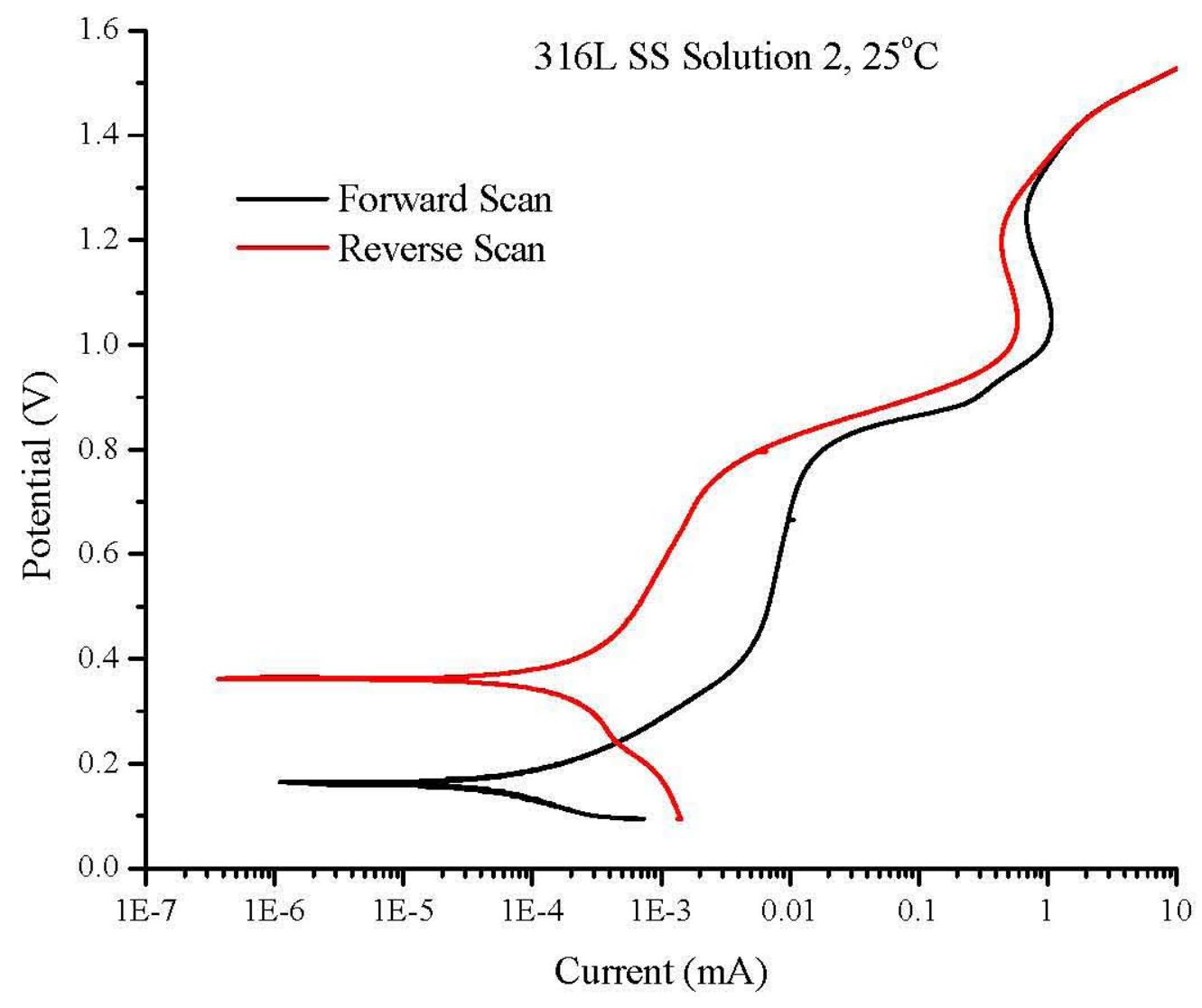


Figure A-6. Cyclic Potentiodynamic Polarization San of 316L Stainless Steel in Solution 3 at $25^{\circ} \mathrm{C}$, Potential Versus Saturated Calomel Electrode.

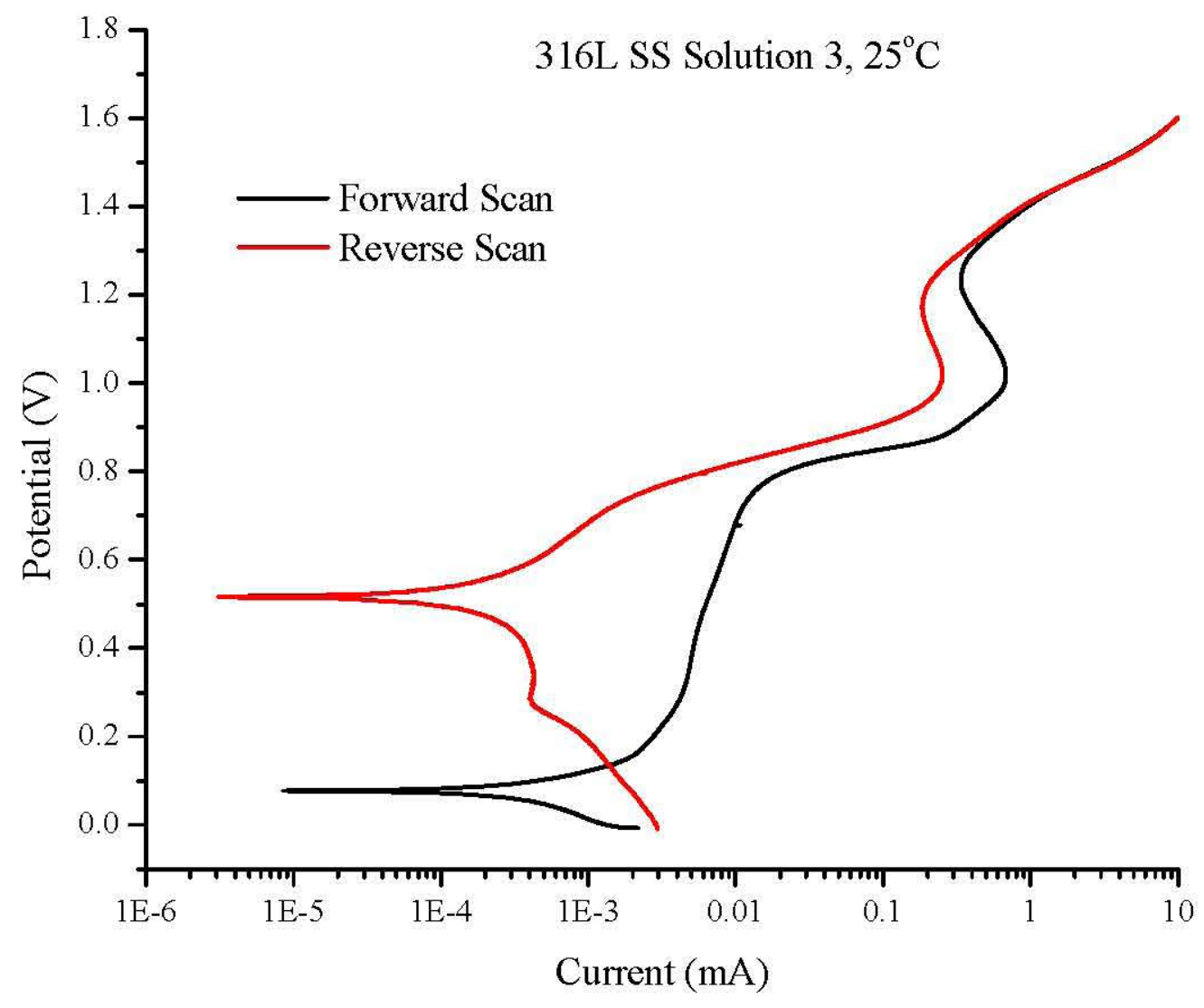


Figure A-7. Cyclic Potentiodynamic Polarization Scan of 304 Stainless Steel in Solution 1 at $60^{\circ} \mathrm{C}$, Potential Versus Saturated Calomel Electrode.

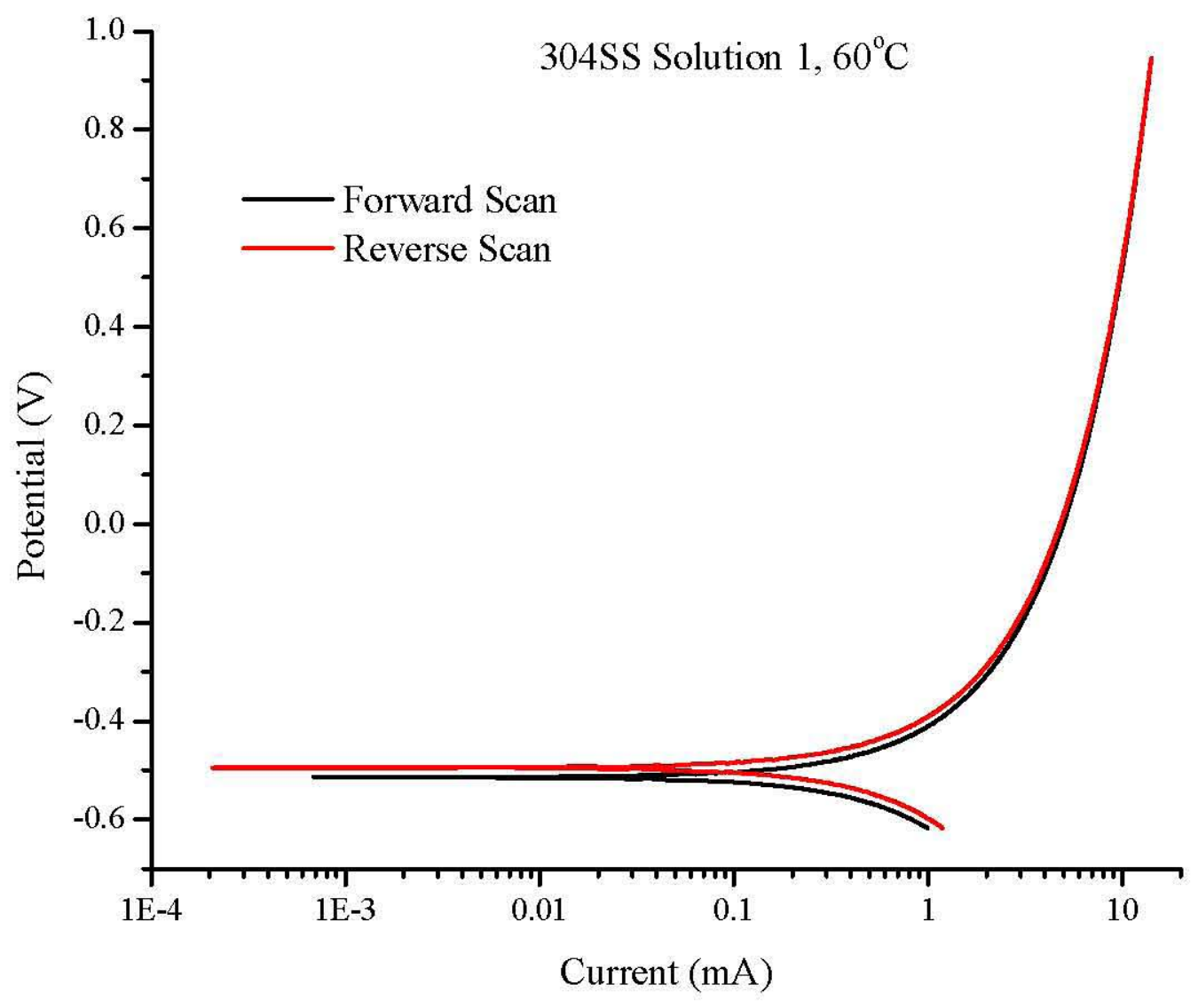


Figure A-8. Cyclic Potentiodynamic Polarization Scan of 304 Stainless Steel in Solution 2 at $60^{\circ} \mathrm{C}$, Potential Versus Saturated Calomel Electrode.

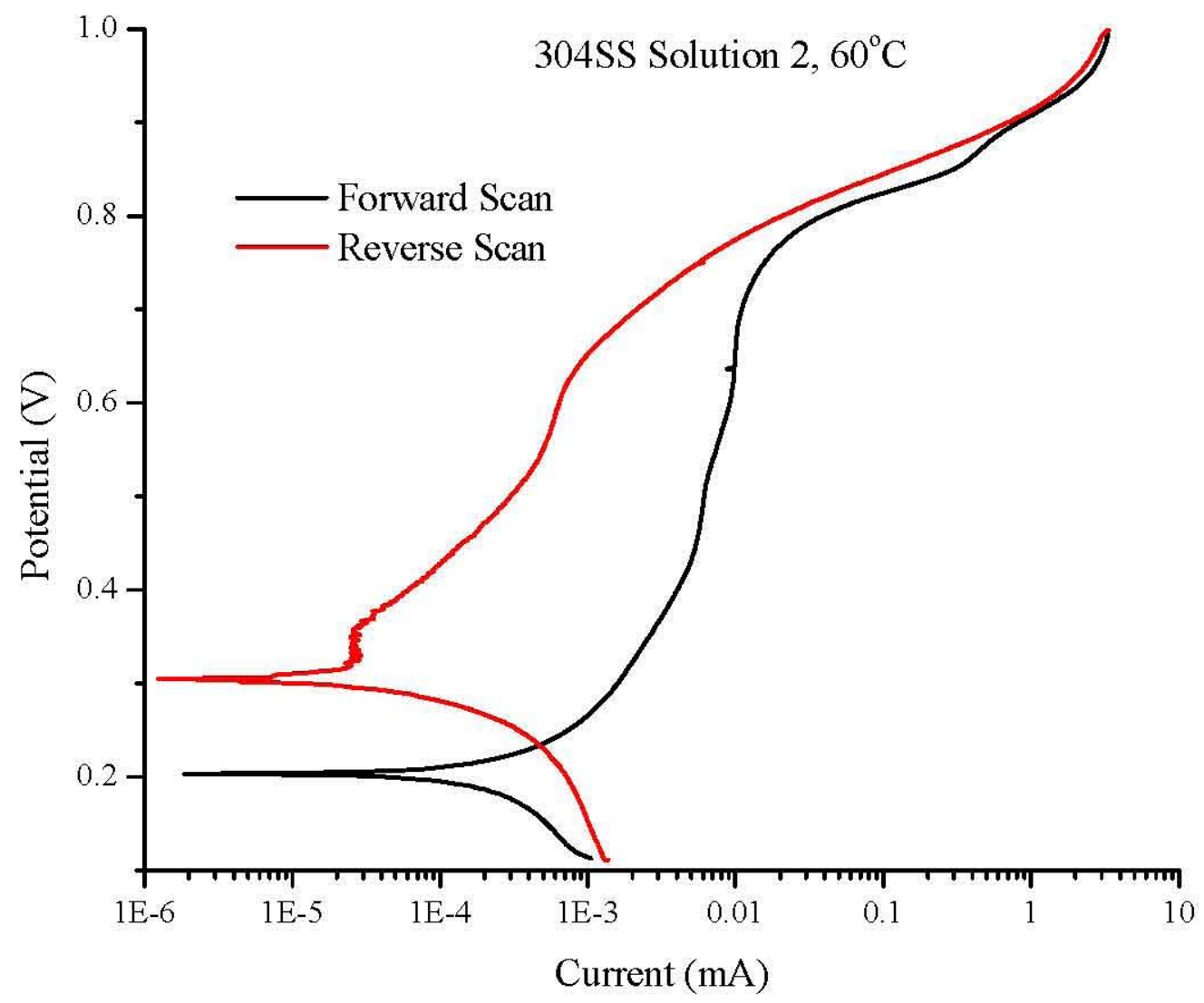


Figure A-9. Cyclic Potentiodynamic Polarization Scan of 304 Stainless Steel in Solution 3 at $60^{\circ} \mathrm{C}$, Potential Versus Saturated Calomel Electrode.

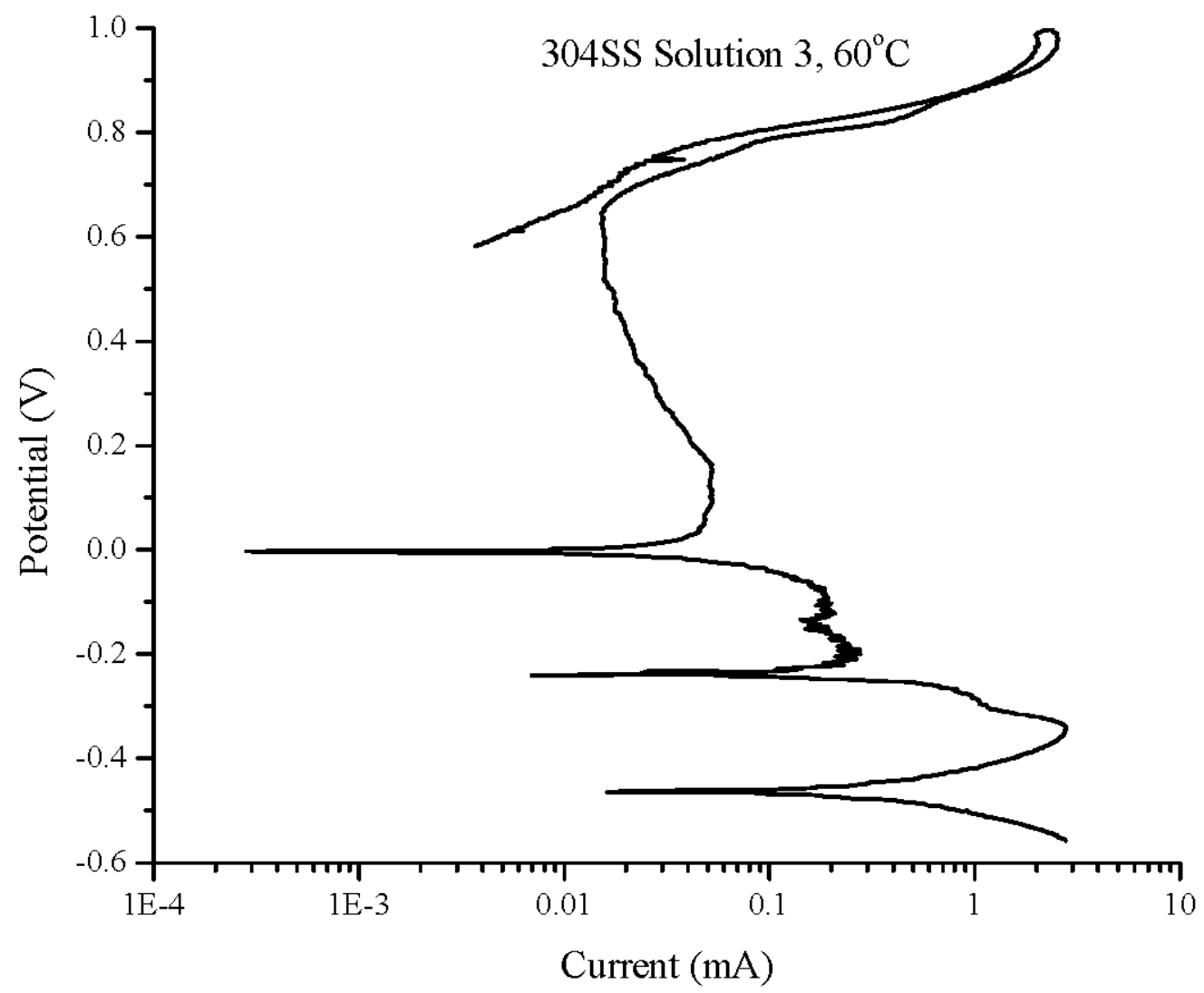


Figure A-10. Cyclic Potentiodynamic Polarization Scan of 316L Stainless Steel in Solution 1 at $60^{\circ} \mathrm{C}$, Potential Versus Saturated Calomel Electrode.

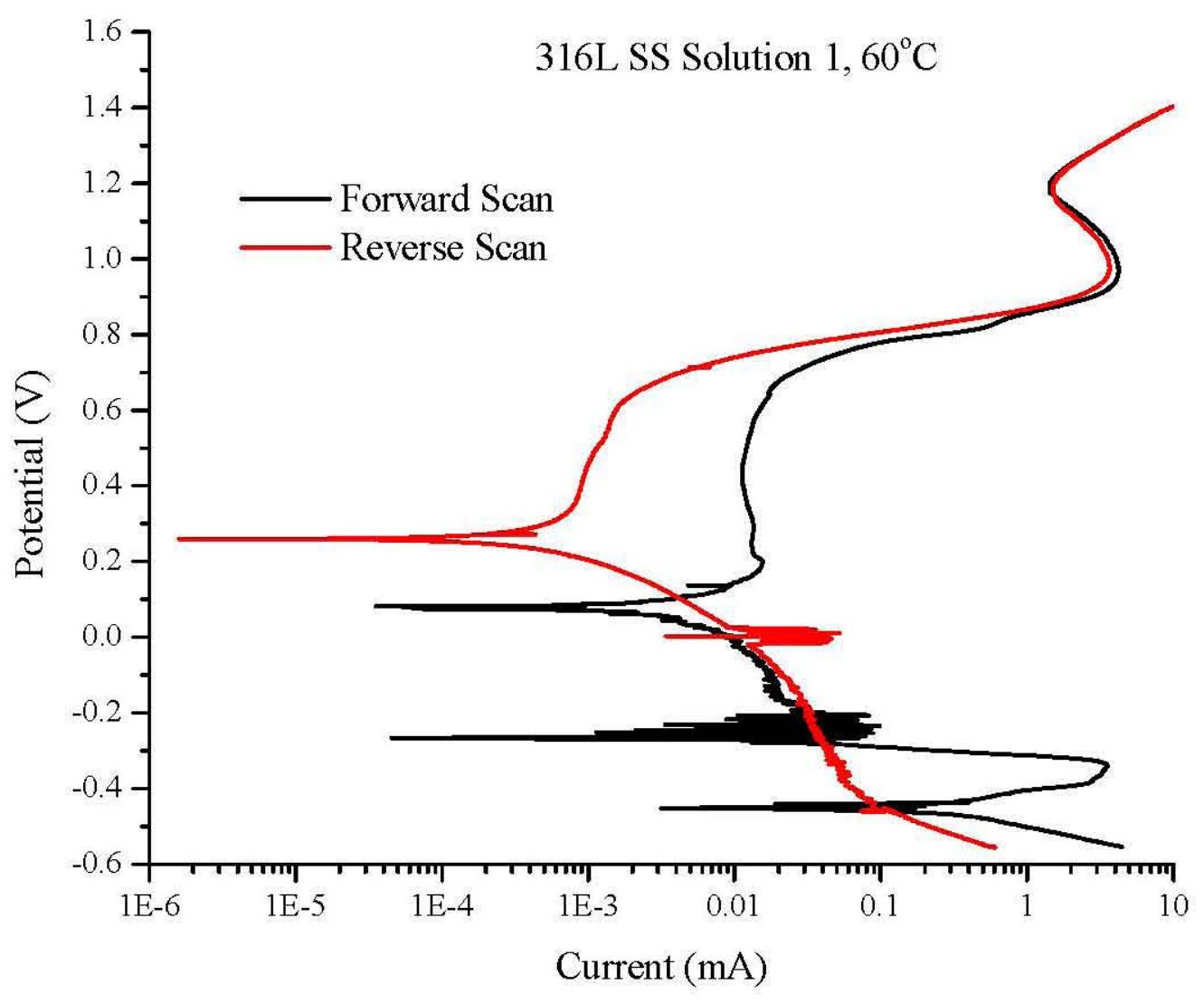


Figure A-11. Cyclic Potentiodynamic Polarization Scan of 316L Stainless Steel in Solution 2 at $60^{\circ} \mathrm{C}$, Potential Versus Saturated Calomel Electrode.

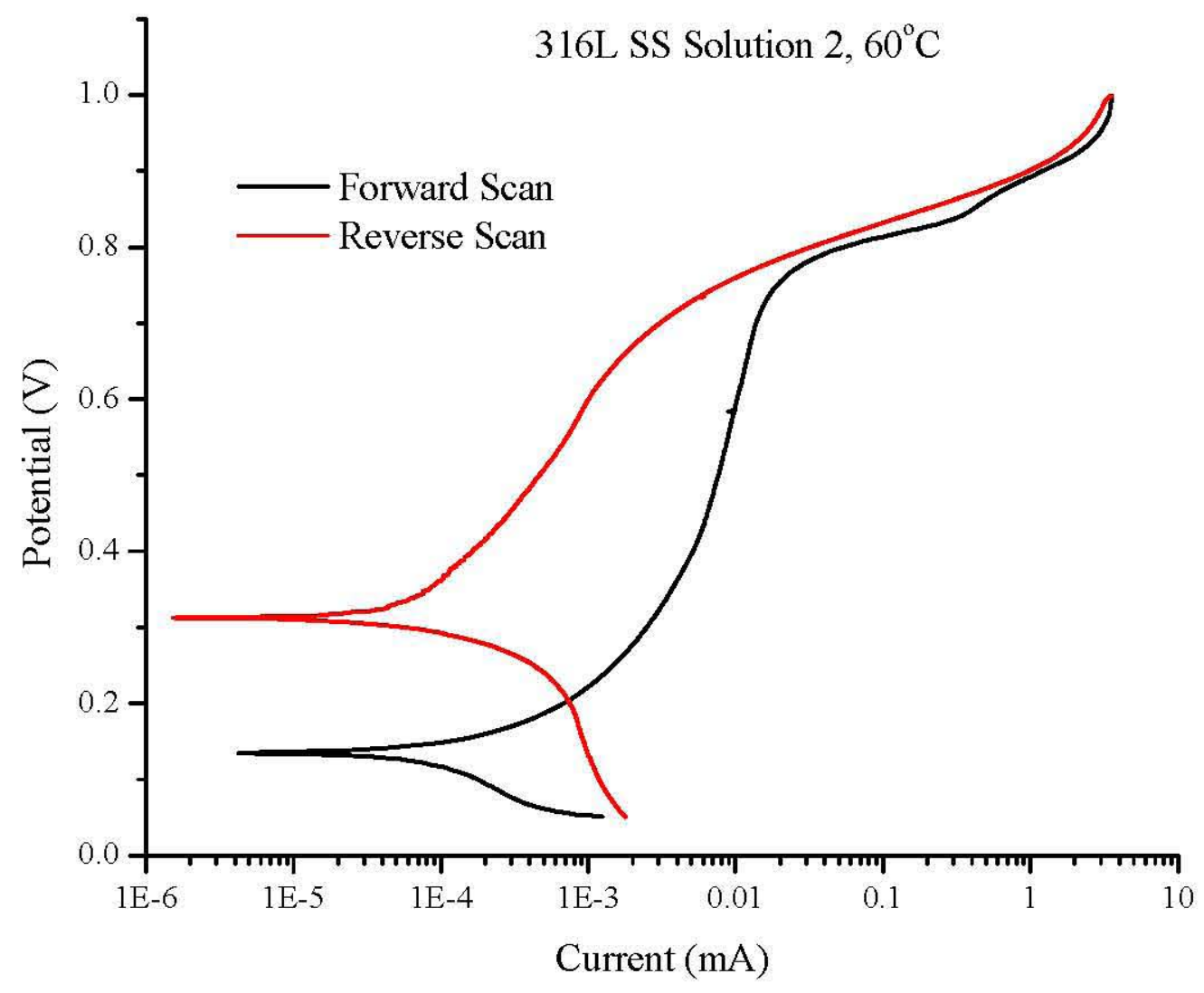


Figure A-12. Cyclic Potentiodynamic Polarization Scan of 316L Stainless Steel in Solution 3 at $60^{\circ} \mathrm{C}$, Potential Versus Saturated Calomel Electrode.

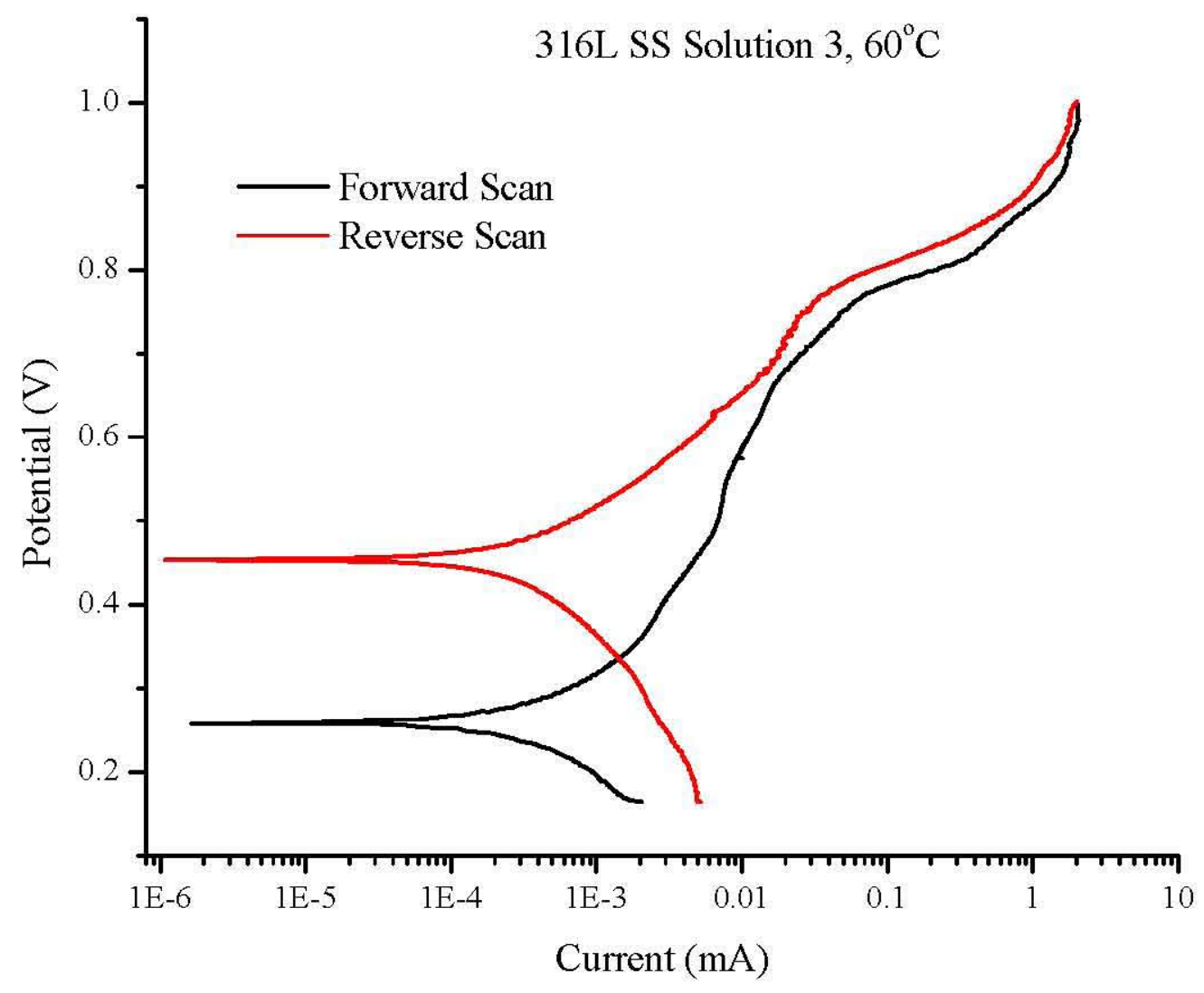


Figure A-13. Cyclic Potentiodynamic Polarization Scan of 304 Stainless Steel in 100-ppm Chloride Solution at $38^{\circ} \mathrm{C}$,

Potential Versus Saturated Calomel Electrode.

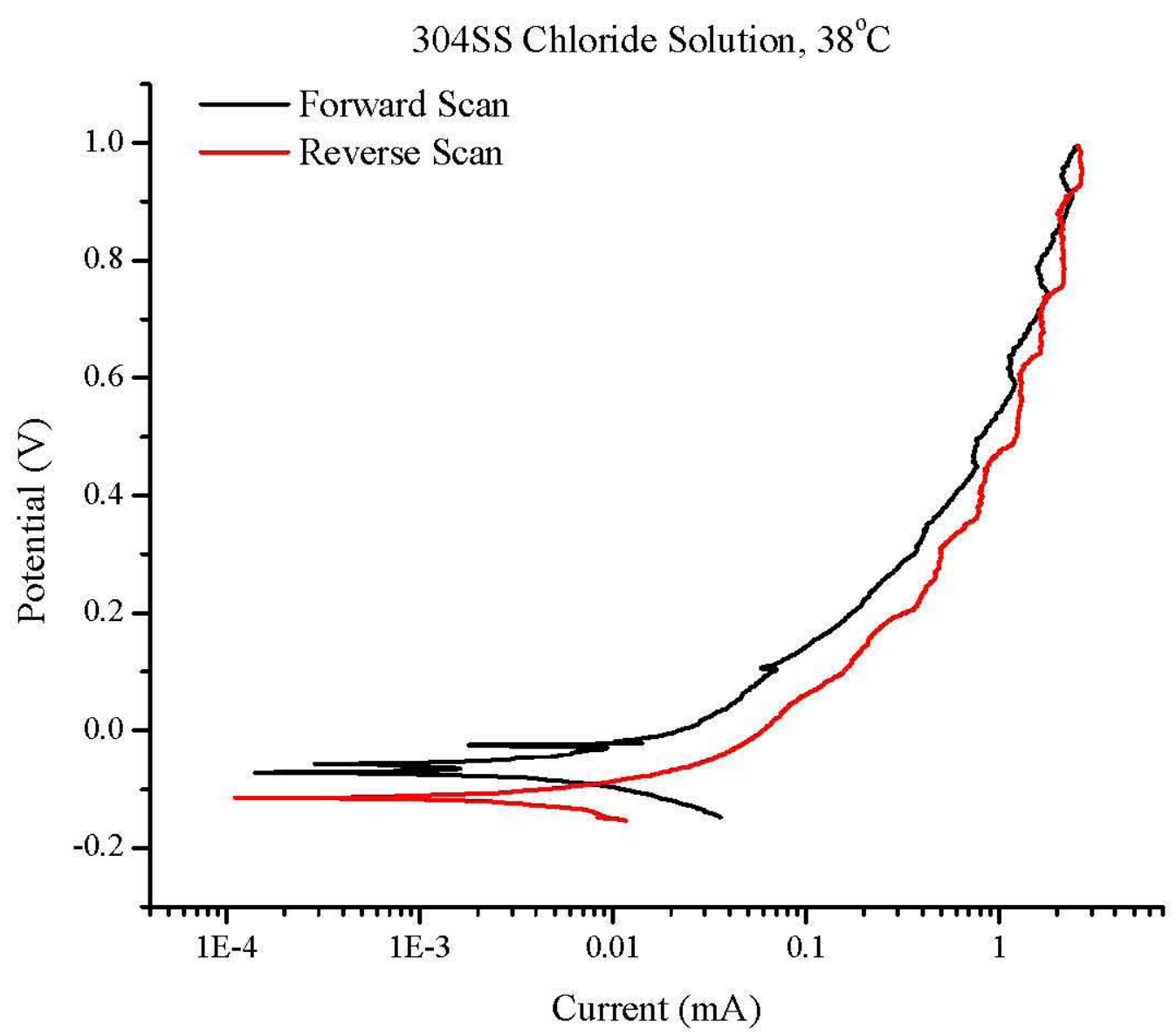


Figure A-14. Cyclic Potentiodynamic Polarization Scan of 316L Stainless Steel in 100-ppm Chloride Solution at $38^{\circ} \mathrm{C}$,

Potential Versus Saturated Calomel Electrode.

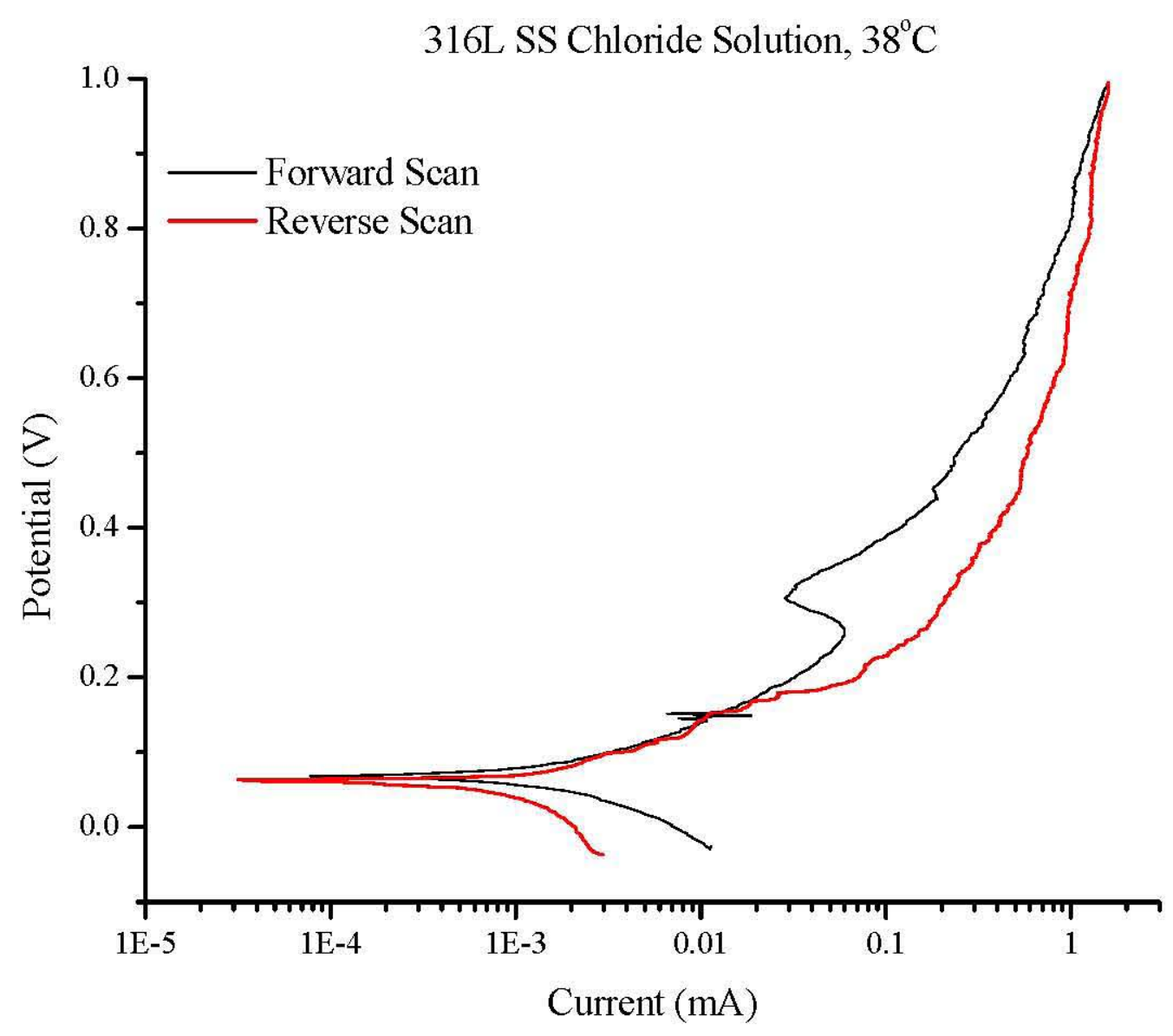

